\title{
EXPERIMENTAL WORKSHOP OF MAKING ROMAN MOSAICS IN THE MUSEUM OF SLAVONIA IN OSIJEK
}

\begin{abstract}
From December 4, 2010 till March 8, 2011 the Museum of Slavonia in Osijek initiated an experimental workshop of making Roman mosaics. There were seven 4-hour sessions in total. Through the production process students were introduced to an indirect technique of making mosaics from start to finish. During short lectures and the making of their own mosaics, students discovered the complexity of the Roman mosaic technique.
\end{abstract}

Keywords: Roman mosaics, experimental workshop, students, Museum of Slavonia in Osijek, antiquity.

Ever since antiquity, mosaic has been considered as an individual art form. There are few ancient written records of mosaic techniques. The most comprehensive description of making mosaics was written by Pliny the Elder. Pliny the Elder categorized it as a decorative technique, while Marcus Vitruvius Pollio did not separate it from architecture and construction (Vitruvije 1951: 149-150). In the 36th volume, 64th chapter of his Natural History series Pliny the Elder describes the technique for preparation of mosaic ground (Pliny the Elder 1885: 36.64). Given both quantity and quality of works, it is safe to say that mosaics were not only widespread, but also highly valued during the Roman rule in the Mediterranean and beyond.

After the fall of the Western Roman Empire, it survived within the Eastern Roman Empire, until its decline in the 15th century. Once highly valued and admired in the ancient world, it became a "forgotten technique" that was not restored to its full glory even during the Renaissance, when many ancient techniques were being rediscovered. Today, mosaic is defined as a painting technique, amalgamating design, painting, sculpture and architecture from its very beginning. The method of making mosaics has not changed much since ancient times. Advancements in tools and materials have made the process quicker and easier but over all the process is the same.

As an archeologist and art historian, I have always been fascinated with mosaics so I decided to organize an experimental workshop for making of Roman mosaics. The target group were upper-elementary school students from Osijek who showed interest and enthusiasm for the project, together with their art teachers. After the initial show of interest, I went on to develop age-appropriate methods. The making of our first mock-mosaic was photographed every step of the way, which allowed me to present the project to art teachers at their county assembly (Osijek-Baranja Coun- 


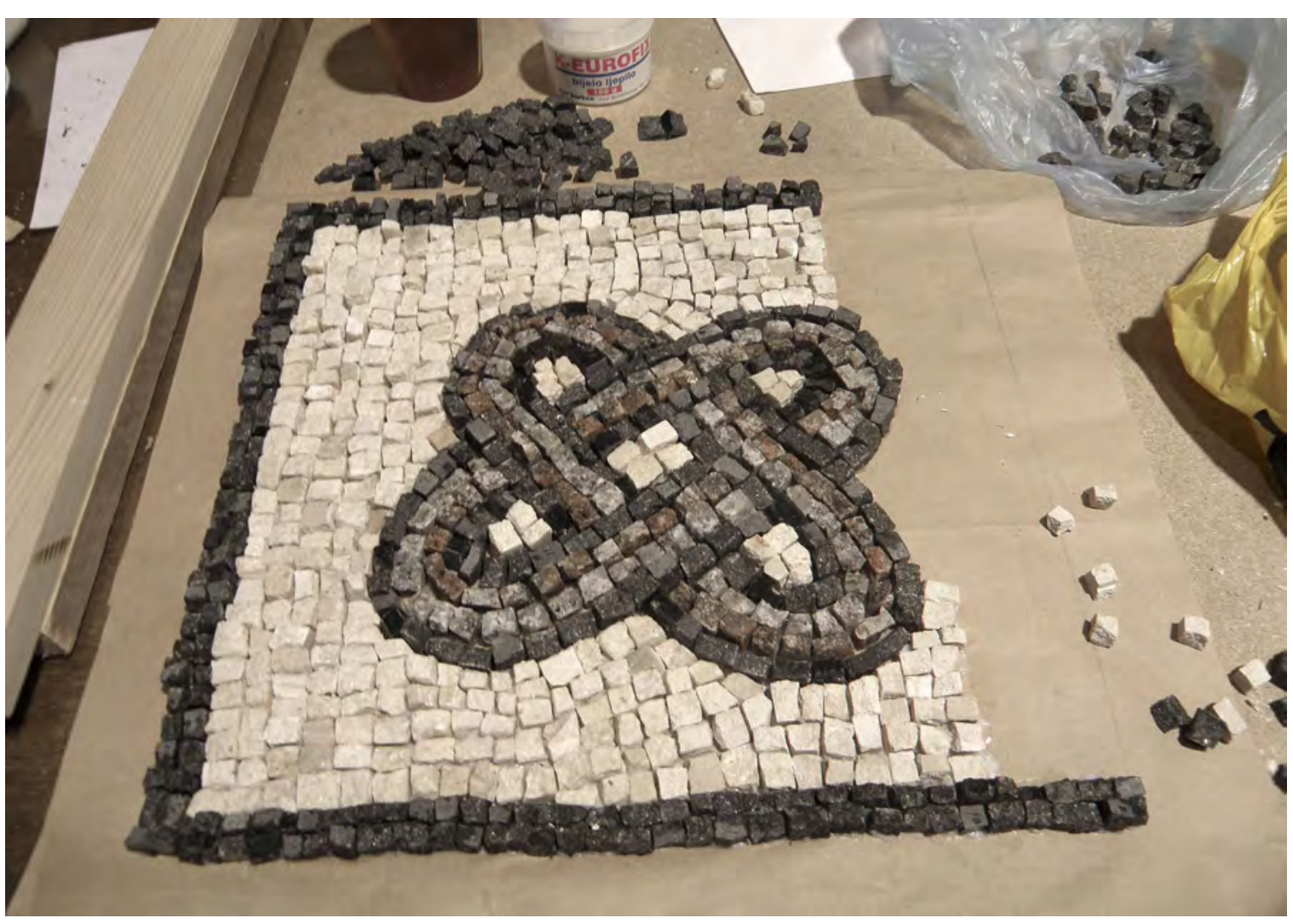

Fig. 1 Making of our first mock-mosaic / Izrada našeg prvog mozaika

ty). There was also a brief lecture on Roman mosaics and production methods. Moreover, I explained my intention to revitalize the production of Roman mosaics among students through these workshops. Other objective were to introduce ancient culture and lifestyle to the target group, to raise awareness about the need to preserve cultural heritage, to develope creativity and stimulate artistic exploration and finally to encourage independence among participants to continue with the workshops either at their school or at home.

Since mosaic-making has not changed significantly over the centuries, the intention was to present it as both an ancient and a modern technique. Primarily, the idea was to approach it as genuinely as possible and present the technique in all its complexity, putting emphasis on the meticulous and time-consuming process of making tesserae, as well as other manufacturing processes.

When the teachers came on board, some of them suggested that members of school art groups would be the most suitable participants. These were mostly students aged 11-14 who were thrilled with the idea of making their own mosaics.
First, there was a brief historical overview, from the mosaic in Uruk to the mosaics of the Late Antique period. In this way, the students were introduced to not only the development of motives and styles, but also to the technical aspects of mosaic production in different civilisations and periods. Then, we continued to describe the procedure of making an actual mosaic which I had created before the workshop. The students could see the making of tesserae and then try to produce the pieces themselves. The rubble stone (marble and granite) was acquired at the local masonry. We cut the stone with a cutter for metal which we built into a wooden log, with the blade facing upwards. We set the stone on the blade and hit it at the right place with a sharp double-pointed hammer to make tesserae which were about $1 \mathrm{~cm}$ in length.

During our next meeting, I showed the participants pictures of some of the most famous Roman mosaics, such as the mosaics at Villa Romana del Casale from the Piazza Armerina on Sicily, mosaics from Pompeii and the mosaics from the Aquileia basilica. The students were particularly interested in figur- 


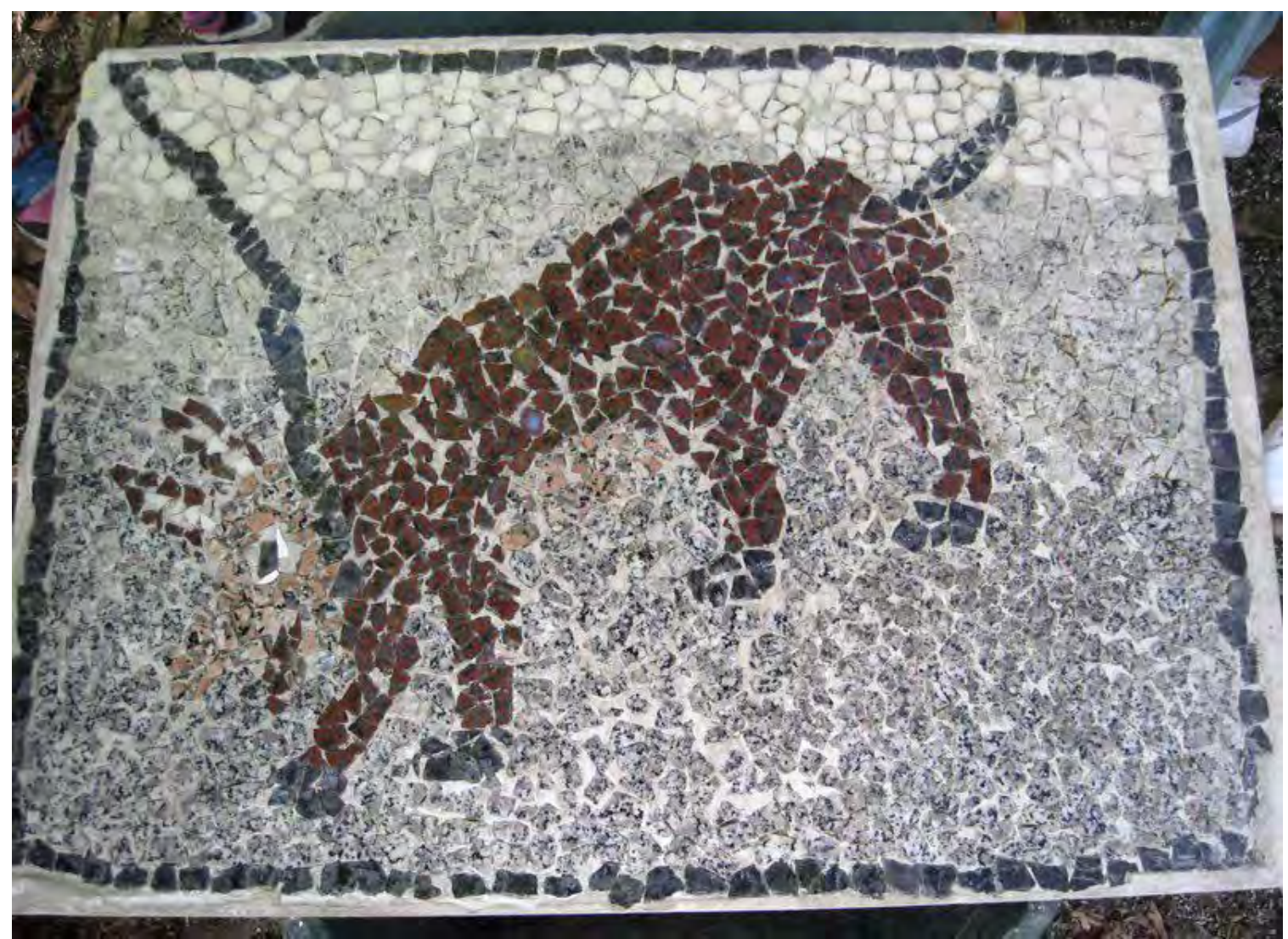

Fig. 2 Cave Canem mock-mosaic made on the second workshop / Cave Canem mozaik izrađen na drugoj radionici

al motives and one of their favorites was the fish. After selecting the motives, we started drawing pencil sketches on kraft paper. The children only made the outlines of the mosaic with a few decorations, to guide them through the rest of the process. After the sketch was drawn, each student chose their own colour of tesserae. To simplify the matter, I decided to apply the indirect method ${ }^{1}$. The students had to put water-based glue on the flattest part of the tessera and paste it on the sketch.

Our next meeting was at the restoration workshop in our museum. The museum art restorer Miroslav Benaković ${ }^{2}$ helped us put up

1 The indirect method is simpler and faster than the direct method but also less harmonious. Tesserae are glued upside down on the sketch with water-based glue and then the mortar or plaster are applied over the back of the tesserae. After that, the mosaic is flipped over, washed and grouted, if needed. The indirect method is optimal for large areas such as wall decorations and compositions made of many small tiles. 2 I want to thank museum art restorer Miroslav Benaković for his help and guidance in process of mosaic- making. a wooden frame which we fixed with clamps. When the frame was built, we prepared a mixture of grey, slow-setting plaster. We placed a glass net, which we had previously prepared, on 1 centimetre of plaster. We applied this procedure twice and poured out the rest of the plaster. This is how we made a solid, 4 centimetre-thick surface.

We left the mosaics to dry for several days and then we removed the frames and flipped the mosaics. We washed off the paper and the glue on top of the mosaics with water, sponges, brushes. Once the mosaics were clean, the students were thrilled with the result and immediately started planning an exhibition at their school.

In the meantime, one of the art teachers from another school volunteered her art group for a workshop, and offered their school as the venue. In only two days, twenty students, aged 11-14, managed to put together a wellknown motive of a dog, called Cave Canem from Pompeii. A colourful mosaic made of marble tesserae is scheduled to be set into a table at their school playground. The same art 


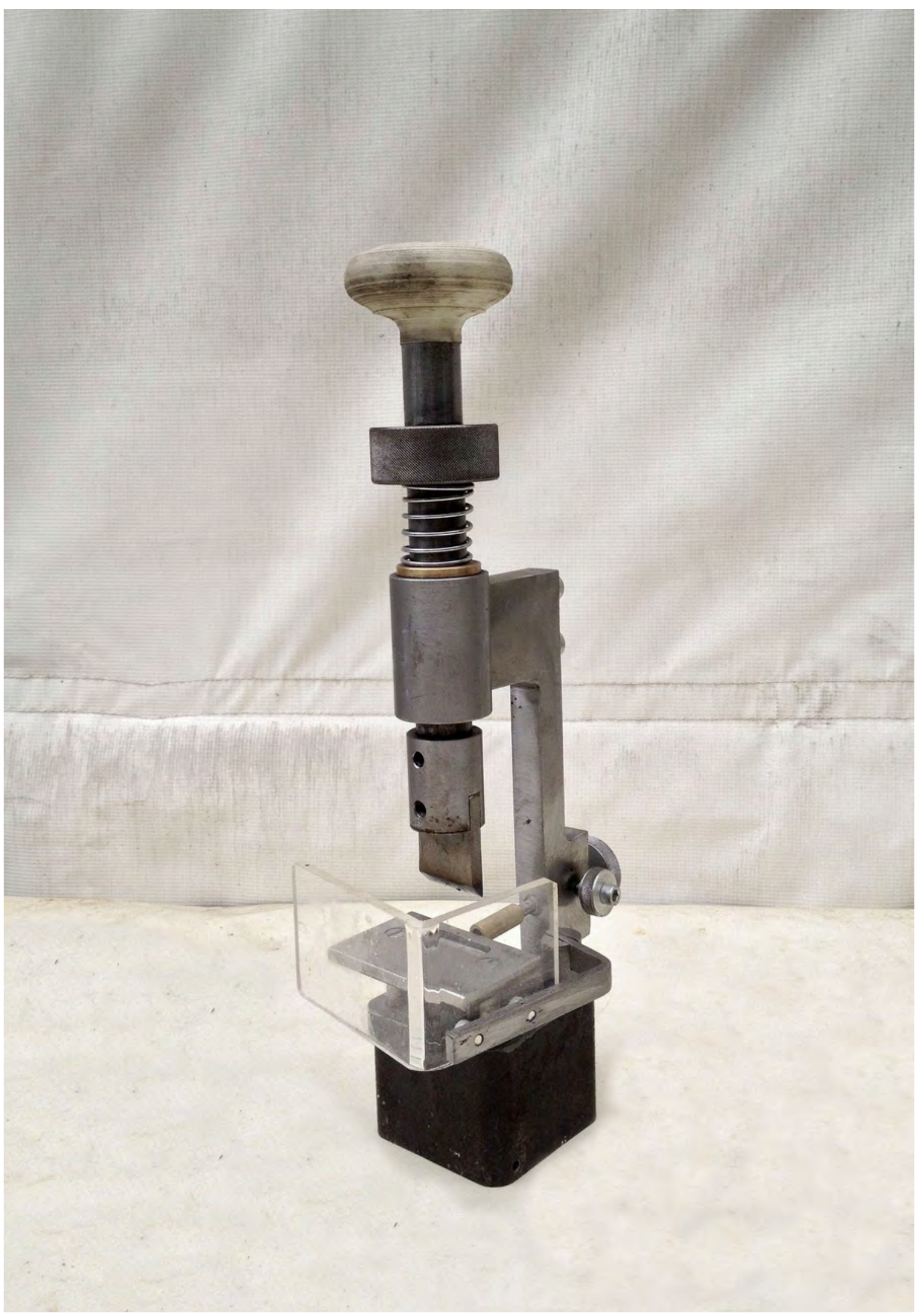

Fig. 3 Our new tesserae cutting device (made by: Miroslav Benaković) / Naš novi rezač tesera (izradio: Miroslav Benaković) 

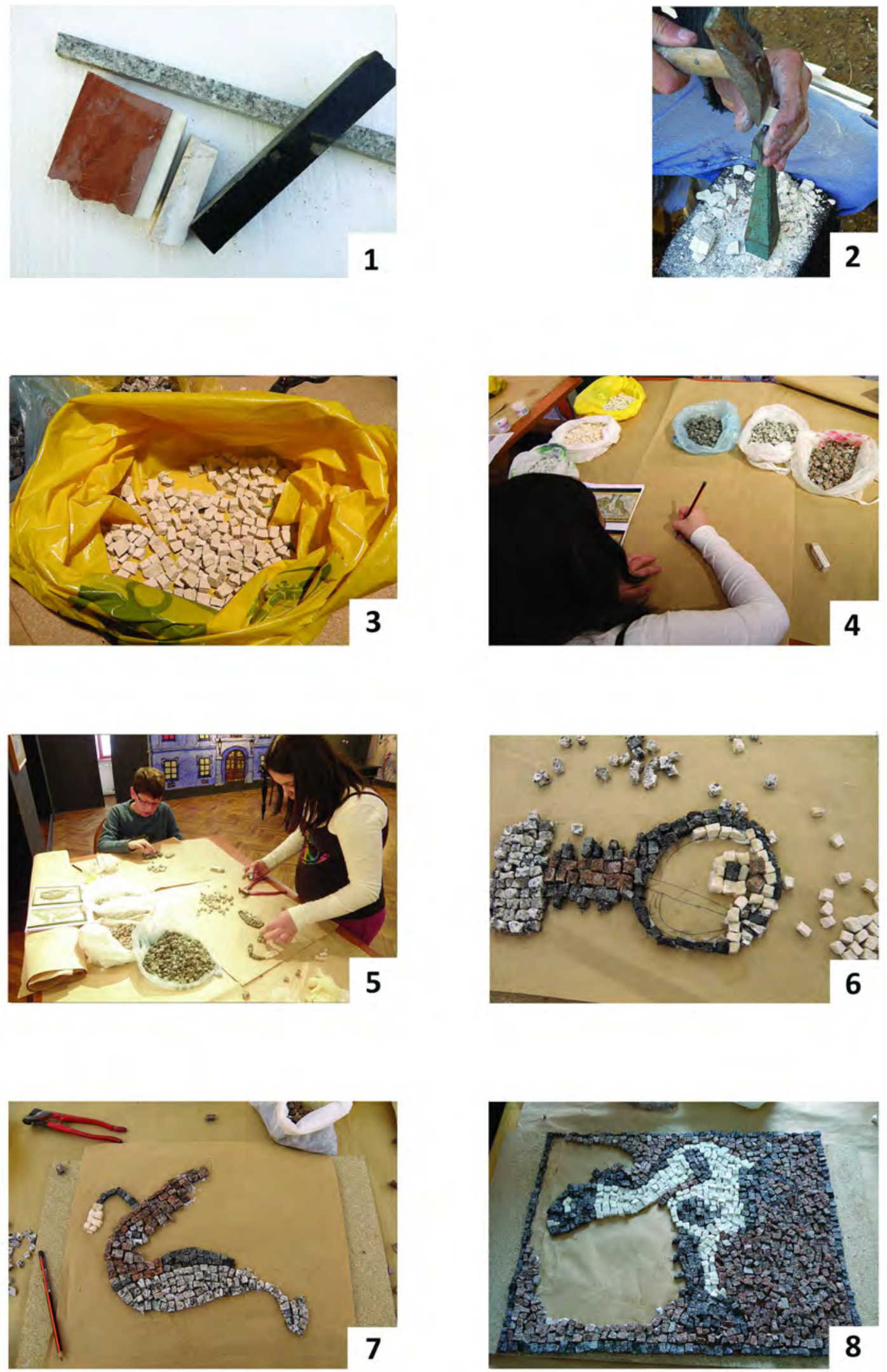

T. 1 Roman mosaic making process - step by step / Proces izrade rimskog mozaika - korak po korak 

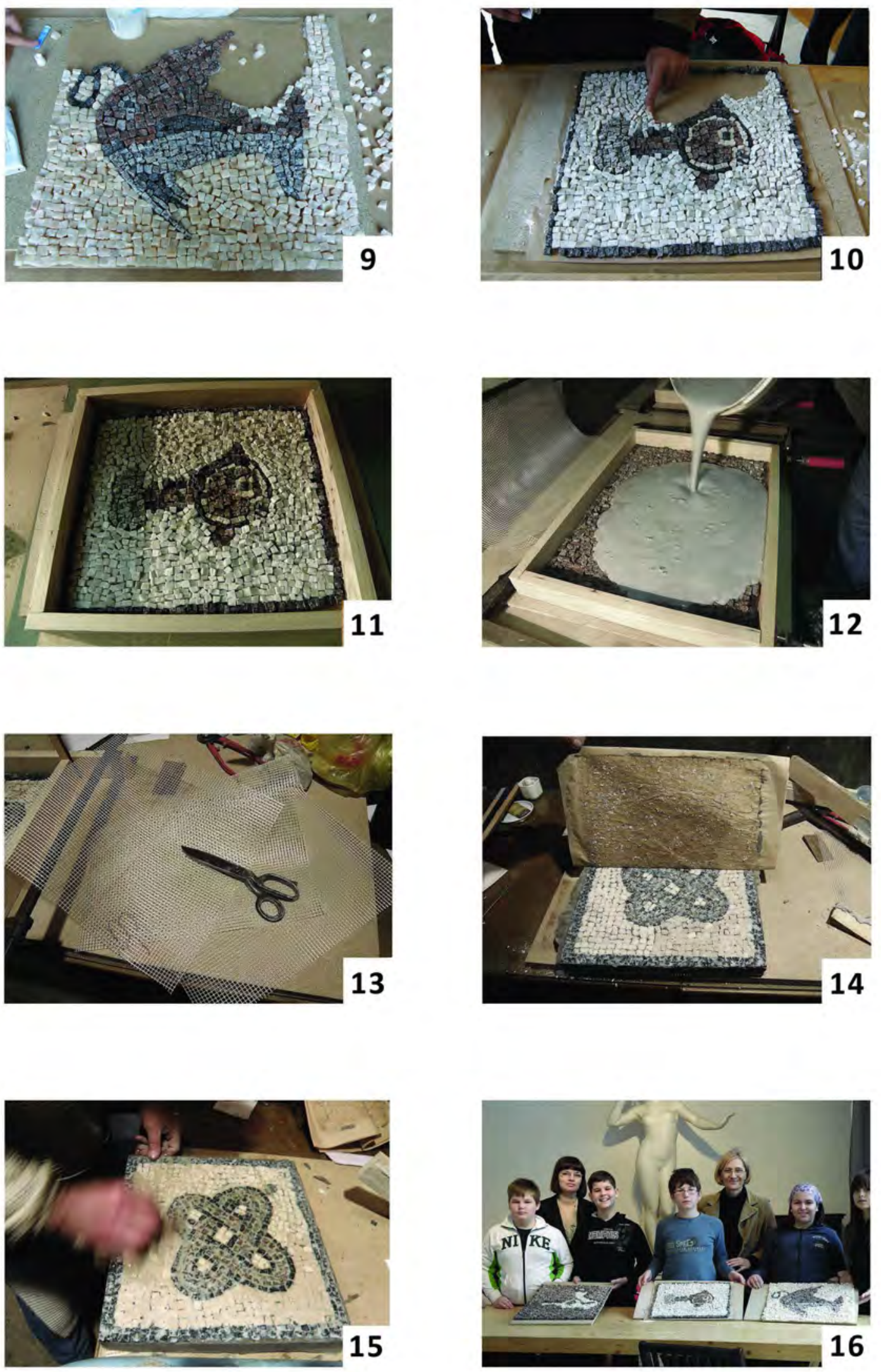

T. 2 Roman mosaic making process - step by step / Proces izrade rimskog mozaika - korak po korak 
group joined our next workshop with similar enthusiasm and helped us make Roman ceramic lamps, which was also a great success.

After the workshops, and more precisely, after the experience of making tesserae the museum art restorer assembled a device for cutting Roman tesserae that is easy and safe to use for children. The workshops allowed us to create four unique mosaics and build a brand new device, which is, in our humble opinion, more than enough for a trial run.

\section{BIBLIOGRAPHY}

\section{Vitruvije 1951}

O arhitekturi, Vitruvijevih deset knjiga o arhitekturi, Matija Lopac (prijevod), Sarajevo: Svjetlost.

\section{Pliny the Elder 1885}

The Natural History (John Bostock, M. D., F. R. S., H. T. Riley, Esq., B. A., Ed.), Boston: Tufts Univerity. Available though Perseus Digital Librarary. http://www.perseus.tufts.edu/hopper/ text?doc=Perseus\%3atext\%3a1999.02.0137 [10. rujna 2012].

\section{REZIME}

\section{EKSPERIMENTALNE RADIONI- CE ZA IZRADU RIMSKIH MO- ZAIKA U MUZEJU SLAVONIJE IZ OSIJEKA}

Ključne riječi: rimski mozaici, eksperimentalne radionice, učenici, Muzej Slavonije u Osijeku, antički period.

Od 4. decembra 2010. do 8. marta 2011. godine Muzej Slavonije u Osijeku pokrenuo je eksperimentalnu radionicu izrade rimskih mozaika. Održano je sedam radionica u trajanju od četiri sata. Ciljana gupa bili su učenici viših razreda osnovnih škola iz Osijeka, koji su pokazali interes i entuzijazam za projekt.

Cilj je bio upoznati osnovnoškolce s antičkom kulturom i načinom života, podići svest o potrebi očuvanja kulturne baštine, razviti kreativnost, potaknuti umetničko istraživanje i konačno potaknuti nezavisnost među sudionicima kako bi nastavi- li s radionicama, bilo u njihovoj školi ili kod kuće.

Kroz proces proizvodnje, objašnjen u ovome radu, učenici su upoznati s indirektnom tehnikom izrade mozaika od početka do kraja. Kroz kratka predavanja i izradu vlastitih mozaika učenici su otkrili složenost rimske mozaičke tehnike. Zbog naših radionica stvorili smo četiri jedinstvena mozaika te izradili potpuno novi uređaj za rezanje mozaičkih kockica - tessera. 